\title{
Toxicity of Andira paniculata (Fabaceae) Extracts to Helicoverpa armigera (Lepidoptera: Noctuidae)
}

\author{
Maurilio de Sousa $\mathrm{Neto}^{1}$, Franciele Cristina da Silva ${ }^{2}$, André Cirilo de Sousa Almeida ${ }^{2}$, \\ Antônio Carlos Severo Menezes ${ }^{3}$, Márcio da Silva Araújo ${ }^{1}$ \& Flávio Gonçalves de Jesus ${ }^{2}$ \\ ${ }^{1}$ School of Agronomy, Universidade Estadual de Goiás, Câmpus Ipameri, Ipameri, Brazil \\ ${ }^{2}$ School of Agronomy, Instituto Federal Goiano, Campus Urutaí, Urutai, Brazil \\ ${ }^{3}$ School of Chemistry, Universidade Estadual de Goías, Câmpus Henrique Santilo, Anápolis, Brazil \\ Correspondence: André Cirilo de Sousa Almeida, School of Agronomy, Instituto Federal Goiano, Campus \\ Urutaí, Urutai, GO, ZIP 75790-000, Brazil. E-mail: andre_cirillo@hotmail.com
}

$\begin{array}{ll}\text { Received: February 25, } 2018 & \text { Accepted: April 8, } 2018 \quad \text { Online Published: May 15, } 2018 \\ \text { doi:10.5539/jas.v10n6p264 } & \text { URL: https://doi.org/10.5539/jas.v10n6p264 }\end{array}$

\begin{abstract}
Helicoverpa armigera is one of the most important pests of soybean crop in Brazil. The purpose of this work was to evaluate the effect of organic Andira paniculata extracts on its biology, feeding and the attractiveness of soybean plants to $H$. armigera. Hexane, dichloromethane, ethyl acetate and hydroalcoholic fractions at concentrations of $0.01,0.1,0.5$ and $1 \%$ were evaluated. For the biological parameters the period and viability of larval stage, caterpillar weight at ten days, period, viability and pupal weight at 24 hours, total longevity, $\mathrm{LC}_{50}$ and deterrence were evaluated. The non-preference for feeding and attractiveness, the number of caterpillars and the dry matter consumed in each fraction of the extracts were evaluated. The extract of $A$. paniculata in hexane $(0.01 \%)$ resulted up to $85 \%$ mortality of $H$. armigera. The $A$. paniculata extract did not affect the larval period, weight, pupal period and mortality or the consumption of $H$. armigera. The hydroalcoholic extracts obtained the better results for deterrence. The $A$. paniculata extract in dichloromethane fraction had the lowest $\mathrm{LC}_{50}$. The $A$. paniculata extracts in the hexane fractions $(0.1 \%)$, ethyl acetate $(0.01$ and $0.5 \%)$ and hydroalcoholic $(0.01$ and $0.5 \%$ ) were fagodeterrents for $H$. armigera. Thus, $A$. paniculata extract in hexane fraction is the most promising for use in the control of H. armigera in soybean.
\end{abstract}

Keywords: antibiosis, antixenosis, botanical insecticide, Glycine max

\section{Introduction}

Helicoverpa armigera (Lepidoptera: Noctuidae) is an agricultural pest that has been registered in over 60 species of cultivated plant such as: soya, beans, cotton, sorghum, corn, tomato, fruit and ornamental plants (Moral Garcia, 2006; Priya et al., 2012). Damage is caused by feeding on the leaves, stem, inflorescences and fruits of the plants, preferably from the plant's reproductive structure such as the shoots, inflorescences, fruits and pods (Kumar \& Saini, 2008; Ali \& Choudhury, 2009). Currently, it is one of the major pests in agricultural crops in Brazil (Czepack et al., 2013; Bueno et al., 2014).

The use of traditional chemical insecticides to control this pest may cause the selection of resistant insects, pest resurgence, elimination of natural enemies and an array of problems in the environment (Patel et al., 1992). For this reason, it is important to investigate new bioactive substances with alternative insecticide characteristics, which are compatible with integrated pest management programs (Maroneze \& Gallegos, 2009; Zotti et al., 2010; Janini et al., 2011).

Overall, botanical insecticides show a broad range of pest insect control, are fairly specific in their mode of action, and further, are harmless to non-target organisms. In addition, they are easily produced by growers and small industries (Talukder \& Howse, 1994; Baskar \& Ignacimuthu, 2012).

Insecticidal plants can cause food intake inhibition, reduction of intestinal motility, interference in the ecdysone synthesis, inhibition in the chitin biosynthesis, deformations both in pupae and adults, decreases in fecundity and longevity, sterilization, inhibition of oviposition and mortality in both immature and adult forms of insects (Koul et al., 2004; Boiça Junior et al., 2005; Baskar et al., 2011; Vendan et al., 2009). 
The insecticide deterrent effect of several plant extracts has been studied in the control of agricultural pests. Very few studies of this nature have been carried out for the pest $H$. armigera. One of them by Baskar et al. (2009) reported deformities in the body of $H$. armigera treated with hexane extract of Atalantia monophylla. The insecticide effect in the population of Spodoptera frugiperda by extracts of Andira paniculata has already been studied by Pereira (2012).

The purpose of this work was to evaluate the toxicity (deterrence, larval and pupal mortality, and inhibition of development) of organic extracts of $A$. paniculata leaves, on H. armigera.

\section{Material and Methods}

The research was carried out in the Laboratory of Agricultural Entomology of the Goiano Federal Institute, Campus Urutai, in Urutaí City, Goiás State, Brazil. The assays were performed in a laboratory at a temperature of $25 \pm 2{ }^{\circ} \mathrm{C}$, relative humidity of $70 \pm 10 \%$, and photoperiod of 12 hours.

\subsection{Rearing and Maintenance of the Insect}

$H$. armigera larvae were fed on an artificial diet. The insects used in the experiment were obtained from a laboratory of a Brazilian company called Bug Biological Agents. After the eclosion of eggs, the larvae continued to feed on the artificial diet until they reached the third instar. Between zero and six hours after ecdysis to the third instar, parts of the soya leaves treated with different extracts of $A$. paniculata were offered to the larvae as food. The soya used was the conventional ND 7337, grown in a greenhouse, in $5.0 \mathrm{~L}$ pots, containing substrate subsoil base, sand and manure, at a ratio of 2:1:1. No pest control with insecticides was carried out during the development of the soya crop in the greenhouse.

\subsection{Plant and Extract Preparation}

A. paniculata leaves were obtained from trees found in the cerrado region in the municipality of Anápolis City, Goiás, Brazil. After collection, the plant matter was dried in a forced air oven at $50^{\circ} \mathrm{C}$ for five days. After this, it was ground and submitted to an exhaustive extraction with ethanol. The filtrate from this extraction was collected and the organic solvent evaporated in a vacuum at a temperature of around $40{ }^{\circ} \mathrm{C}$, producing the crude ethanolic extract.

The crude ethanolic extract of the leaves was fractionated by liquid-liquid extraction, resuspended in ethanol-water solution 3:1, in increasing polarity order: hexane, dichloromethane and ethyl acetate, thereby obtaining the fractions: $A$. paniculata leaf extracts-hexane fraction (APFE-H), A. paniculata leaf extracts-dichloromethane fraction (APFE-D), A. paniculata leaf extracts-ethyl acetate fraction (APFE-A), and $A$. paniculata leaf extracts-hydro alcoholic (APFE-W).

To prepare the extracts, $1.0 \mathrm{~g}$ of the following fractions were used: hexane, ethyl acetate and hydro alcoholic, in addition to a $0.46 \mathrm{~g}$ fraction of dichloromethane. The fractions APFE-H, APFE-D, and APFE-A were dissolved in acetone and water (1:1), and the fraction APFE-W was dissolved in ethanol and water (1:1), all in a $1 \%$ concentration. Test tubes with the solutions were placed in ultra-sound to provide complete dissolution.

In the treatments, the following concentrations were used: APFE-H: $0.01 \%, 0.1 \%, 0.5 \%$ and $1 \%$; APFE-D: $0.01 \%, 0.1 \%, 0.5 \%$, and $1 \%$; APFE-A: $0.01 \%, 0.1 \%, 0.5 \%$, and $1 \%$; APFE-W: $0.01 \%, 0.1 \%, 0.5 \%$ and $1 \%$, and the control (distilled water).

Soya leaf discs ( $2.5 \mathrm{~cm}$ of diameter) were immersed in concentrations of the extracts and control for 30 seconds, after which, they were placed outside for 1.5 hours, under dry paper towel to ensure complete evaporation of the solvents used.

\subsection{Bioassay-Antibiosis Effect}

Newly hatched $H$. armigera larvae were individualized in $9.0 \mathrm{~cm}$ diameter Petri dishes with moist filter paper. The larvae were fed with soya leaves treated with plant extracts at different concentrations. These dishes were kept under controlled conditions (temperature $25 \pm 2{ }^{\circ} \mathrm{C}$, UR $70 \pm 10 \%$, and photoperiod of 12 hours), where the leaves were replaced daily.

Larval mortality was recorded daily until pupal phase. The surviving larvae were weighed 10 days after the beginning of the experiment and the pupae were removed from the dishes 24 hours after development, then weighed and replaced in the dish for the emergence of adults. The moths were not given food during the adult phase. 
The biological variables evaluated were: a) larval phase: period and viability of larval phase, and larval weight 10 days after feeding; b) pupal phase: period and pupal viability, and weight at 24 hours of age; c) total cycle. A completely randomized design with 17 treatments and 20 repetitions was used.

\subsection{Bioassay-Antixenosis Effect}

In free choice attractivity trials with third instar larvae, soya leaf discs $(2.5 \mathrm{~cm}$ in diameter $)$ treated with plant extract, were distributed equidistant in trays (arena with $350 \mathrm{~mm}$ of diameter) and lined with moist filter paper, where the larvae had access to food.

For the dry matter consumed, two leaf discs $\left(2.5 \mathrm{~cm}^{2}\right.$ diameters $)$ were removed equidistantly from the soybean leaves. One was offered to the insects and the other, known as the aliquot, was oven dried at $60{ }^{\circ} \mathrm{C}$ for 48 hours. The dry matter consumed by $H$. armigera larvae was determined by the difference between this rate and the remaining portion of the disc consumed.

The deterrence percentage of the discs of soya leaves treated with different extracts for the $H$. armigera larvae were determined according to Singh and Pant (1980):

Preference index for $\mathrm{H}$. armigera on the soya leaf discs treated with plant extracts was determined according to Kogan and Goeden (1970): PI = 2A/(M+A); being, PI = preference index, A = leaf area treated with extract and consumed by the larvae, $\mathrm{M}=$ leaf area not treated with plant extracts consumed by larvae.

\subsection{Statistical Analysis}

The data were submitted to ANOVA test and the means compared by the use of Scott-Knott to 5\% probability, using R software (R Core Team, 2016).

\section{Results}

The larval weight of $H$. armigera fed with soya treated with different $A$. paniculata extracts was significantly affected $(P<0.0001)$ by the other variables analyzed (Table 1$)$. The duration of the larval period $(P=0.8498)$, and pupal period $(P=0.3916)$, pupal weight $(P=0.1798)$, and total life cycle $(P=0.8991)$ were not influenced by the plant extract fractions. Larval weight was lower in larvae fed with the following fractions: Hexane 0.01 and $0.10 \%$, Dichloromethane $0.10 \%$, Acetate Ethyl 0.5 and $1 \%$, and Hydro alcoholic 0.10 and 1\%, which differed statistically from the other concentrations, presenting higher means, varying between 0.09 and $0.11 \mathrm{~g}$. 
Table 1. Duration of larval, pupal and total life cycle (days) periods, larval and pupal weight (g) of Helicoverpa armigera fed with soya leaves treated with different extract concentrations of Andira paniculata

\begin{tabular}{|c|c|c|c|c|c|}
\hline $\begin{array}{l}\text { Concentration } \\
\text { of extract }(\%)\end{array}$ & $\begin{array}{l}\text { Duration of larval } \\
\text { period (days) }\end{array}$ & $\begin{array}{l}\text { Larval weight } \\
(\mathrm{g})\end{array}$ & $\begin{array}{l}\text { Duration of pupal } \\
\text { period (days) }\end{array}$ & $\begin{array}{l}\text { Pupal weight } \\
\text { (g) }\end{array}$ & $\begin{array}{l}\text { Duration of total } \\
\text { life cycle (days) }\end{array}$ \\
\hline \multicolumn{6}{|l|}{ Hexane } \\
\hline 0.01 & $24.00 \pm 2.31$ & $0.07 \pm 0.01 \mathrm{~b}$ & -1 & $0.16 \pm 0.03$ & - \\
\hline 0.10 & $26.50 \pm 1.45$ & $0.07 \pm 0.00 \mathrm{~b}$ & $13.20 \pm 0.97$ & $0.15 \pm 0.01$ & $42.20 \pm 2.46$ \\
\hline 0.50 & $23.50 \pm 0.38$ & $0.09 \pm 0.00 \mathrm{a}$ & $13.29 \pm 0.92$ & $0.18 \pm 0.01$ & $42.29 \pm 1.08$ \\
\hline 1.00 & $23.18 \pm 0.86$ & $0.10 \pm 0.01 \mathrm{a}$ & $14.89 \pm 0.48$ & $0.16 \pm 0.01$ & $42.11 \pm 0.75$ \\
\hline \multicolumn{6}{|c|}{ Dichloromethane } \\
\hline 0.01 & $2392 \pm 0.73$ & $0.11 \pm 0.01 \mathrm{a}$ & $13.25 \pm 0.63$ & $0.14 \pm 0.01$ & $39.50 \pm 0.50$ \\
\hline 0.10 & $24.50 \pm 0.67$ & $0.06 \pm 0.01 \mathrm{~b}$ & $14.00 \pm 1.58$ & $0.16 \pm 0.02$ & $41.25 \pm 1.25$ \\
\hline 0.50 & $22.58 \pm 0.82$ & $0.11 \pm 0.01 \mathrm{a}$ & $13.67 \pm 0.48$ & $0.14 \pm 0.01$ & $40.92 \pm 0.82$ \\
\hline 1.00 & $24.17 \pm 1.01$ & $0.09 \pm 0.01 \mathrm{a}$ & $13.11 \pm 0.45$ & $0.15 \pm 0.01$ & $41.67 \pm 0.69$ \\
\hline \multicolumn{6}{|l|}{ Ethyl acetate } \\
\hline 0.01 & $24.08 \pm 1.03$ & $0.09 \pm 0.01 \mathrm{a}$ & $13.91 \pm 0.48$ & $0.15 \pm 0.01$ & $41.27 \pm 0.95$ \\
\hline 0.10 & $23.00 \pm 0.80$ & $0.11 \pm 0.01 \mathrm{a}$ & $13.78 \pm 0.52$ & $0.15 \pm 0.01$ & $42.11 \pm 0.79$ \\
\hline 0.50 & $24.00 \pm 2.21$ & $0.08 \pm 0.01 \mathrm{~b}$ & $14.25 \pm 0.48$ & $0.15 \pm 0.01$ & $40.75 \pm 0.75$ \\
\hline 1.00 & $23.67 \pm 0.76$ & $0.08 \pm 0.00 \mathrm{~b}$ & $13.30 \pm 0.40$ & $0.16 \pm 0.01$ & $41.60 \pm 0.67$ \\
\hline \multicolumn{6}{|l|}{ Hydro alcoholic } \\
\hline 0.01 & $24.25 \pm 0.78$ & $0.09 \pm 0.01 \mathrm{a}$ & $13.36 \pm 0.28$ & $0.16 \pm 0.01$ & $41.21 \pm 0.71$ \\
\hline 0.10 & $23.13 \pm 0.82$ & $0.08 \pm 0.00 \mathrm{~b}$ & $12.33 \pm 0.32$ & $0.13 \pm 0.00$ & $41.17 \pm 0.68$ \\
\hline 0.50 & $23.45 \pm 1.00$ & $0.09 \pm 0.01 \mathrm{a}$ & $14.00 \pm 0.44$ & $0.12 \pm 0.01$ & $42.00 \pm 0.79$ \\
\hline 1.00 & $22.83 \pm 1.17$ & $0.08 \pm 0.01 \mathrm{~b}$ & $13.80 \pm 0.42$ & $0.15 \pm 0.01$ & $42.50 \pm 1.28$ \\
\hline Control & $23.42 \pm 0.62$ & $0.10 \pm 0.01 \mathrm{a}$ & $13.30 \pm 0.40$ & $0.15 \pm 0.01$ & $42.40 \pm 0.73$ \\
\hline $\mathrm{F}$ & $0.6373^{\mathrm{ns}-}$ & $3.4888^{*-}$ & $1.0696^{\mathrm{ns}}$ & $1.3395^{\mathrm{ns}}$ & $0.5723^{\mathrm{ns}}$ \\
\hline$P$ & 0.8498 & $<0.0001$ & 0.3916 & 0.1798 & 0.8991 \\
\hline
\end{tabular}

Note. Mean \pm Standard deviation error followed by the same letter, do not differ statistically between themselves by the use of Scott-Knott test at 5\% probability. ${ }^{*}$ Significant at 1 and $5 \%$ probability, respectively. ${ }^{1}$ Insufficient number of repetitions for a reliable statistical analysis due to the mortality in pupal phase or emergence of adults with visible anomalies. ${ }^{\text {ns }}$ Non significant.

The A. paniculata extracts did not cause significant changes in either the duration of the period, nor pupal weight, nor in the duration of the $H$. armigera life cycle (Table 1 ). However, they influenced $H$. armigera larval mortality $(P<0.0109)$, whereas pupal mortality did not differ statistically from each other $(P=1501)$ (Table 2$)$. Regarding larval mortality, the highest means were found in the $0.01,0.10$ and $0.5 \%$ Hexane fractions, which reached 85,70 and $60 \%$, respectively. In $0.1 \%$ Dichloromethane fraction with $65 \%$ mortality, and in $0.5 \%$ Acetate Ethyl fraction, which reached $70 \%$ mortality. Larval mortality varied between 25 and $50 \%$ in the other fractions, which did not differ statistically from the control treatment. 
Table 2. Consumption of dry mass by the larvae, larval mortality, pupal mortality and deterrence of Helicoverpa armigera fed with soya leaves treated with different concentrations of Andira paniculata extract

\begin{tabular}{|c|c|c|c|}
\hline Concentration of extract $(\%)$ & Dry mass consumed (mg) & Larval mortality (\%) & Pupal mortality (\%) \\
\hline \multicolumn{4}{|l|}{ Hexanic } \\
\hline 0.01 & $3.30 \pm 1.00$ & $85.00 \pm 08.19 \mathrm{a}$ & $33.33 \pm 33.33$ \\
\hline 0.1 & $2.30 \pm 0.99$ & $70.00 \pm 10.51 \mathrm{a}$ & $16.67 \pm 16.67$ \\
\hline 0.5 & $2.10 \pm 0.73$ & $60.00 \pm 11.24 \mathrm{a}$ & $12.50 \pm 12.50$ \\
\hline 1.0 & $2.60 \pm 0.72$ & $45.00 \pm 11.41 \mathrm{~b}$ & $18.18 \pm 12.19$ \\
\hline \multicolumn{4}{|l|}{ Dichloromethane } \\
\hline 0.01 & $2.60 \pm 0.72$ & $40.00 \pm 11.24 b$ & $66.66 \pm 14.21$ \\
\hline 0.1 & $3.10 \pm 0.98$ & $65.00 \pm 10.95 \mathrm{a}$ & $33.33 \pm 21.08$ \\
\hline 0.5 & $2.80 \pm 0.69$ & $40.00 \pm 11.24 b$ & $08.33 \pm 08.33$ \\
\hline 1.0 & $3.70 \pm 0.83$ & $40.00 \pm 11.24 b$ & $25.00 \pm 13.05$ \\
\hline \multicolumn{4}{|l|}{ Ethyl acetate } \\
\hline 0.01 & $3.50 \pm 1.11$ & $40,00 \pm 11.24 b$ & $08.33 \pm 08.33$ \\
\hline 0.1 & $2.70 \pm 1.04$ & $40.00 \pm 11.24 b$ & $25.00 \pm 13.05$ \\
\hline 0.5 & $3.10 \pm 0.98$ & $70.00 \pm 10.51 \mathrm{a}$ & $33.33 \pm 21.08$ \\
\hline 1.0 & $3.10 \pm 0.98$ & $40.00 \pm 11.24 b$ & $16.67 \pm 11.23$ \\
\hline \multicolumn{4}{|l|}{ Hydro alcoholic } \\
\hline 0.01 & $1.60 \pm 0.52$ & $40.00 \pm 11.24 b$ & $08.33 \pm 08.33$ \\
\hline 0.1 & $2.50 \pm 0.92$ & $25.00 \pm 09.93 b$ & $16.67 \pm 11.23$ \\
\hline 0.5 & $1.50 \pm 0.54$ & $50.00 \pm 11.41 b$ & $30.00 \pm 15.27$ \\
\hline 1.0 & $3.30 \pm 1.00$ & $40.00 \pm 11.24 b$ & $42.85 \pm 20.20$ \\
\hline Control & $2.40 \pm 0.68$ & $40.00 \pm 11.24 \mathrm{~b}$ & $16.67 \pm 11.23$ \\
\hline $\mathrm{F}$ & $0.54^{\mathrm{ns}^{-} \cdots}$ & $2.0348^{*}$ & $1.3977^{\mathrm{ns}-\cdots}$ \\
\hline$P$ & 0.9179 & 0.0109 & 0.1501 \\
\hline
\end{tabular}

Note. Mean \pm Standard deviation error followed by the same letter, did not differ statistically between themselves, by the use of Scott-Knott test at $5 \%$ probability. ${ }^{*}$ Significance at 1 and $5 \%$ probability, respectively. ${ }^{\text {ns }}$ Non-significant.

Deterrence effects were observed in the following fractions: Hexane $0.10 \%$ and Acetate Ethyl 0.01 and $0.5 \%$ (Figure 1). Nevertheless, the greatest deterrence effects were observed in the Hydro alcoholic fraction in 0.01 and $0.5 \%$ concentrations. The other fractions showed phagostimulant effects.

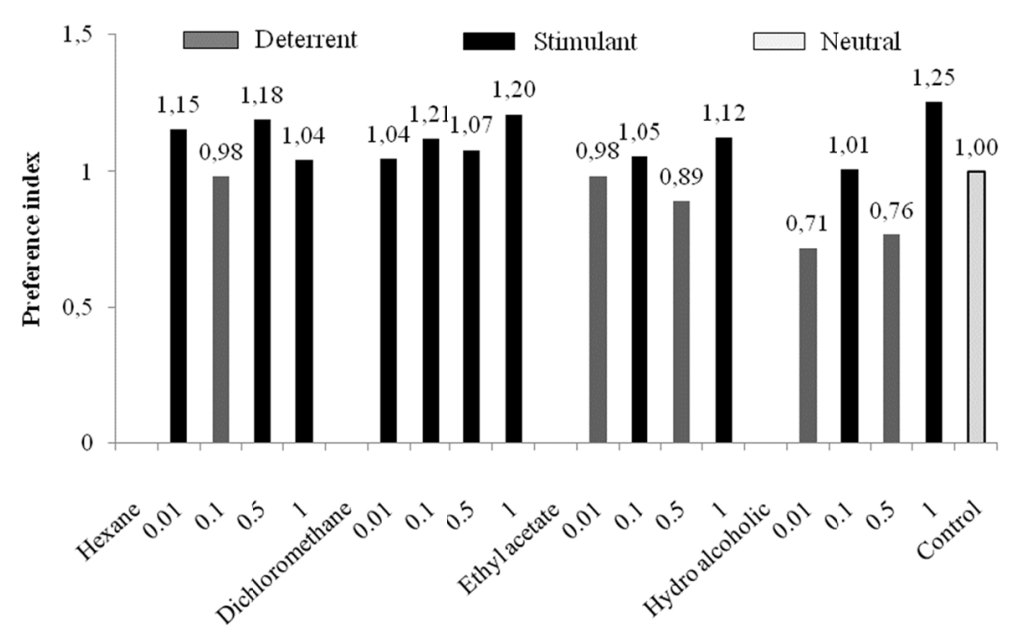

Figure 1. Food preference index of Helicoverpa armigera larvae on soya leaf discs treated with different concentrations (\%) of Andira paniculata in a free choice test 


\section{Discussion}

The A. paniculata extracts, with different fractionations and concentrations analyzed, clearly caused adverse effects in H. armigera biology (antibiosis) during the larval phase, very few of which caused any degree of feeding deterrence to $H$. armigera larvae. Other variables analyzed, such as consumption of dry matter by the larvae, pupal weight, pupal mortality and duration of larval pupal and total periods, were not affected by different forms of fractionation and different extract concentrations, when compared to the control.

The fractions of the A. paniculata extracts led to a larval mortality of up to $85 \%$, and pupal mortality of up to $66 \%$ in $H$. armigera. The mortality data did not show a relation to dose dependency. Despite being proportionately different, our results corroborate with those of Pereira (2012), who observed high larvicidal effects (100\% of mortality) on S. frugiperda when fed with a diet containing the fractions of acetate ethyl and dichlomethane of $A$. paniculata.

The hydro alcoholic fractions $(0.01$ and $0.5 \%)$ and acetate ethyl $(0.01$ and $0.5 \%)$ of $A$. paniculata were the ones that promoted a certain degree of deterrence in $H$. armigera larvae (Figure 1), which takes into account the leaf area consumed in each treatment, when compared to the respective control. The non-maintenance of the feeding may be associated with the activity of plant extracts fed by the larvae or in their complex chemoreception system, causing the deterrence effect (Baskar et al., 2011; Vendan et al., 2009; Baskar \& Ignacimuthu, 2012). However, in this work, the comparison made in the amount of dry matter per larva, on the whole, has not been observed (Table 2).

In addition to the negative effect on larval development (impairment in its weight and mortality), the ingestion of the $A$. paniculata extract caused visible anomalies in different stages of numerous $H$. armigera individuals (Figure 1). However, it was not possible to quantify or qualify these anomalies in this study, however, data were collected for use in future studies. Anomalies or impairment in the development of $H$. armigera treated with hexane extract of other plants such as Atalantia monophylla and Cassia tora were described by Baskar et al. (2009), and Baskar and Ignacimuthu (2012). These anomalies in the H. armigera stages caused by the A. paniculata fractions, may have occurred due to the deterrent effect or physiological complications following ingestion of food treated with plant extracts (Chen et al., 1995).

Our results demonstrated that $A$. paniculata extracts had a larvicidal effect on $H$. armigera, with the highest mortality rate found with the hexane fraction. In addition to the larval mortality caused by this plant extract, the food preference index (PI), where all the highest extract concentration analyzed (1\%) had a phagostimulant effect (Figure 2), suggested that these plant extracts can be pulverized over crops and readily ingested by the larvae, thus, indicating its bio insecticide potential.

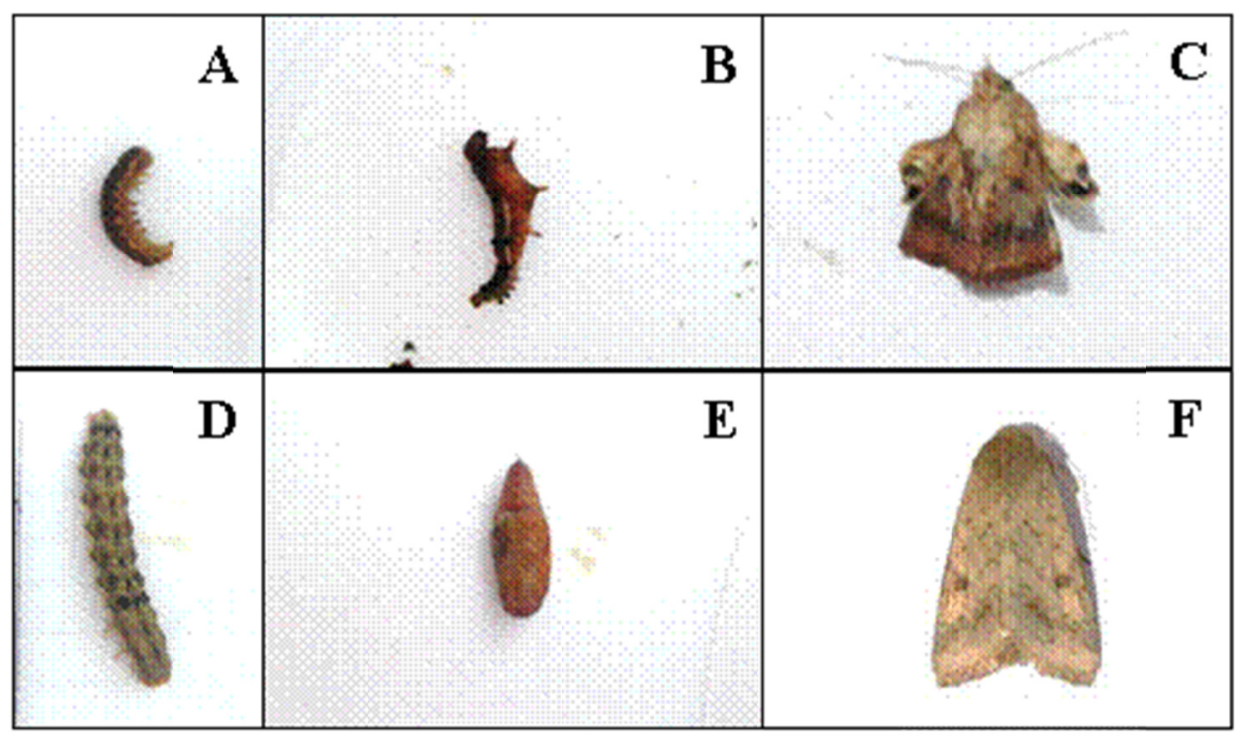

Figure 2. Images of anomalies found in the $H$. armigera population fed with soya $+A$. paniculata extracts. (A, B, C); Normal individuals (D, E, F) 


\section{Acknowledgements}

We would like to thank the Universidade Estadual de Goiás (through the Program BIP/UEG), Instituto Federal Goiano, Conselho Nacional de Desenvolvimento Científico e Tecnológico (CNPq) and the Coordenação de Aperfeiçoamento de Pessoal de Nível Superior (CAPES) for their financial support with research funding.

\section{Reference}

Abbott, W. S. (1925). A method of computing the effectiveness of an insecticide. Journal of Economic Entomology, 18, 265-266. https://doi.org/10.1093/jee/18.2.265a

Ali, A., \& Choudhury R. A. (2009). Some biological characteristics of Helicoverpa armigera on chickpea. Tunisian Journal of Plant Protection, 4, 99-106.

Baska, K., \& Ignacimuthu, S. (2012). Antifeedant, larvicidal and growth inhibitory effects of ononitol monohydrate isolated from Cassia tora L. against Helicoverpa armigera (Hub.) and Spodoptera litura (Fab.) (Lepidoptera: Noctuidae). Chemosphere, 88, 384-388. https://doi.org/10.1016/j.chemosphere.2012.02.051

Baskar, K., Kingsley, S., Vendan, S. E., Paulraj, M. G., Duraipandiyan, V., \& Ignacimuthu, S. (2009). Antifeedant, larvicidal and pupicidal activities of Atalantia monophylla (L.) Correa against Helicoverpa armigera (Hubner) (Lepidoptera: Noctuidae). Chemosphere, 75, 355-359.10.1016/j.chemosphere.2008. 12.034

Baskar, K., Maheswaran, R., Kingsley, S., \& Ignacimuthu, S. (2011b). Bioefficacy of plant extracts against Asian armyworm Spodoptera litura Fab. (Lepidoptera: Noctuidae) larvae. Journal of Agricultural Technology, 7, 123-131.

Boiça Junior, A. L., Medeiros, C. A. M., Torres, A. L., \& Chagas Filho, N. R. (2005). Efeito de extratos aquosos de plantas no desenvolvimento de Plutella xylostella (L.) (Lepidoptera: Plutellidae) em couve. Arquivos do Instituto Biologico, 72, 45-50.

Bueno, R. C. O. F., Yamamoto, P. T., Carvalho, M. M., \& Bueno, N. M. (2014). Occurrence of Helicoverpa armigera (Hübner, 1808) on citrus in the state of Sao Paulo, Brazil. Revista Brasileira de Fruticultura, 36, 520-523. https://doi.org/10.1590/0100-2945-357/13

Chen, W., Isman, M. B., \& Chiu, S. F. (1995). Antifeedant and growth inhibitory effects of the limonoid toosendanin and Melia toosendan extracts on the variegated cutworm Peridroma saucia. Journal of Applied Entomology, 119, 367-370. https://doi.org/10.1111/j.1439-0418.1995.tb01302.x

Czepak, C., Albernaz, K. S., Vivan, L. M., Guimarães, H. O., \& Carvalhais, T. (2013). Primeiro registro de ocorrência de Helicoverpa armigera (Hübner) (Lepidoptera: Noctuidae) no Brasil. Pesquisa Agropecuária Tropical, 43, 110-113. https://doi.org/10.1590/S1983-40632013000100015

Duraipandiyan, V., Ignacimuthu, S., \& Paulraj, M. G. (2011). Antifeedant and larvicidal activities of Rhein isolated from the flowers of Cassia fistula L. Saudi Journal of Biological Science, 18, 129-133. https://doi.org/10.1016/j.sjbs.2010.12.009

Janini, J. C., Boiça Junior, A. L., Jesus, F. G., Carbonell, S. A. M., \& Chiorato, A. F. (2011). Effect of beans genotypes, insecticides, and natural products on the control of Bemisia tabaci (Gennadius) biotype B (Hemiptera: Aleyrodidae) and Caliothrips phaseoli (Hood) (Thysanoptera: Thripidae). Acta Scientiarum Agronomy, 33, 445-450. https://doi.org/10.4025/actasciagron.v33i3.7577

Kogan, M, \& Goeden, R. D. (1970). The host-plant range of Lematrilineata daturaphila (Coleoptera: Chrysomelidae). Annals of the Entomological Society of America, 63, 1175-1180. https://doi.org/10.1093/ aesa/63.4.1175

Koul, O., Singh, G., Singh, R., \& Multani, J. S. (2005). Bioefficacy and mode-of-action of aglaroxin A from Aglaia elaeagnoidea (syn. A. roxburghiana) against Helicoverpa armigera and Spodoptera litura. Entomologia Experimentalis et Applicata, 114, 197-204. https://doi.org/10.1111/j.1570-7458.2005.00259.x

Kumar, S., \& Saini, R. K. (2008). Feeding preference and damage potential of Helicoverpa armigera (Hubner) on different promising cotton genotypes/hybrid. Journal of Agricultrual Science and Technology, 10, 411-420.

Maroneze, D. M., \& Gallegos, D. M. N. (2009). Effect of Melia azedarach aqueous extract on the development of immature and reproductive stages of Spodoptera frugiperda (J. E. Smith, 1797) (Lepidoptera: Noctuidae). Semina, 30, 537-550. https://doi.org/10.5433/1679-0359.2009v30n3p537 
Moral Garcia, F. J. (2006). Analysis of the spatiotemporal distribution of Helicoverpa armigera (Hübner) in a tomato field using a stochastic approach. Biosystems Engineering, 93, 253-259. https://doi.org/10.1016/ j.biosystemseng.2005.12.011

Murray, K. D., Alford, A. R., Groden, E., Drummond, F. A., Storch, R. H., Bentley, M. D., \& Sugathapala, P. M. (1993). Interactive effects of an antifeedant used with Bacillus thuringiensis var. San diego delta-endotoxin on Colorado potato beetle (Coleoptera: Chrysomelidae). Journal of Economic Entomology, 86, 1793-1801. https://doi.org/10.1093/jee/86.6.1793

Patel, C. C., Mehta, D. M., Patel, J. R., \& Patel, N. M. (1992). Resistance of gram pod borer Helicoverpa armigera (Hubner) to insecticides in Gujarat. Indian Jouranl of Agricutural Sciences, 62, 421-423.

Pavunraj, M., Muthu, C., Ignacimuthu, S., Janarthanan, S., Duraipandiyan, V., Raja, N., \& Vimalraj, S. (2011). Antifeedant activity of a novel 6-(4,7-hydroxy-heptyl) quinone from the leaves of the milkweed Pergularia daemia on the cotton bollworm Helicoverpa armigera (Hub.) and the tobacco armyworm Spodoptera litura (Fab.). Phytoparasitica, 39, 145-150. https://doi.org/10.1007/s12600-010-0141-5

Pereira, A. P. N. (2012). Avaliação da atividade inseticida das folhas de Andira paniculata Benth (Fabaceae) (p. 70, Dissertação (Mestrado), Universidade Estadual de Goiás, Anápolis).

Priya, G. N., Ojha, A., Kajla, M. K., Raj, A., \& Rajagopal, R. (2012). Host plant induced variation in gut bacteria of Helicoverpa armigera. PLoS One, 7, 307-318. https://doi.org/10.1371/journal.pone.0030768

R Core Team. (2016). R: A language and environment for statistical computing. Vienna, AT: R Foundation for Statistical Computing. Retrieved from http://www.R-project.org

Singh, R. P., \& Pant, N. C. (1980). Hymenocallis littoralis Salisb as antifeedant to desert locust, Schistocera gregaria Forsk. Indian Journal of Entomology, 42, 460-464.

Talukder, F. A., \& Howse, P. E. (1994). Laboratory evaluation of toxic repellent properties of the pithraj tree, Aphanamixis polystachya Wall \& Parker, against Sitophilus oryzae (L.). International Journal of Pest Management, 40, 274-279. https://doi.org/10.1080/09670879409371897

Vendan, S. E., Baskar, K., Paulraj, M. G., \& Ignacimuthu, S. (2009). Antifeedant and larvicidal effects of Hydnocarpus alpine Wt. (Flacourtiaceae) extracts against the larvae of Helicoverpa armigera Hub. (Lepidoptera: Noctuidae). In S. Ignacimuthu, \& B. V. David (Eds.), Ecofriendly insect pest management (pp. 210-216). Elite Publishing House, New Delhi, India.

Zotti, M. J., Grützmacher, A. D., Grützmacher, D. D., Castilhos, R. V., \& Martins, J. F. S. (2010). Seletividade de inseticidas usados na cultura do milho para ovos e ninfas do predador Doru lineare (Dermaptera: Forficulidae). Arquivos do Instituto Biologico, 77, 111-118.

\section{Copyrights}

Copyright for this article is retained by the author(s), with first publication rights granted to the journal.

This is an open-access article distributed under the terms and conditions of the Creative Commons Attribution license (http://creativecommons.org/licenses/by/4.0/). 